\title{
Regulatory T cells: roles of T cell receptor for their development and function
}

\author{
$\operatorname{AUTHOR}(\mathrm{S})$ :
}

Ohkura, Naganari; Sakaguchi, Shimon

\section{CITATION:}

Ohkura, Naganari ... [et al]. Regulatory T cells: roles of T cell receptor for their development and function. Seminars in immunopathology 2010, 32(2): 95-106

\section{ISSUE DATE:}

2010-06

URL:

http://hdl.handle.net/2433/128837

\section{RIGHT:}

The original publication is available at www.springerlink.com; この論文 は出版社版でありません。引用の際には出版社版をご確認ご利用くだ さい。; This is not the published version. Please cite only the published version. 


\title{
Regulatory $T$ cells: roles of $T$ cell receptor for their development and function
}

\author{
Naganari Ohkura ${ }^{1,2}$ and Shimon Sakaguchi ${ }^{1,2}$ \\ ${ }^{1}$ Department of Experimental Pathology, Institute for Frontier Medical Sciences, Kyoto \\ University, Kyoto 606-8507, Japan \\ ${ }^{2}$ WPI Immunology Frontier Research Center, Osaka University, Suita 565-0871, Japan
}

Contact: Naganari Ohkura or Shimon Sakaguchi, Department of Experimental Pathology, Institute for Frontier Medical Sciences, Kyoto University, 53 Shogoin Kawahara-cho, Sakyo-ku, Kyoto 606-8507. Phone: +81-75-751-3851; Fax: +81-75-751-3820; E-mail: nohkura@frontier.kyoto-u.ac.jp, shimon@frontier.kyoto-u.ac.jp 


\section{Summary}

Naturally arising $\mathrm{CD} 4^{+} \mathrm{CD} 25^{+}$regulatory $\mathrm{T}$ cells (Treg cells), which specifically express the forkhead family transcription factor Foxp3, are essential for the maintenance of immunological self-tolerance and immune homeostasis. Stimulation of the $\mathrm{T}$ cell antigen receptor (TCR) via recognizing self-peptide/MHC is required for their expression of Foxp3 in the course of their development in the thymus. The TCR repertoires displayed by Treg cells and naïve $\mathrm{T}$ cells are apparently distinct, suggesting that Treg cells with high reactivity to self-peptide/MHC ligands are somehow driven to Treg cell lineage in the thymus. Treg cells also require stimulation via TCR to exert suppression in the periphery. At the molecular level, assembly of Foxp3, Foxp3-interacting factors, and chromatin-remodeling factors, is in part under the control of TCR signaling, and TCR stimulation alters Foxp3-dependent transcriptional regulation, protein-protein interaction, and Foxp3 recruitment to the specific genomic loci. These findings collectively indicate that the TCR signaling is essential for suppressive function of Treg cells and that TCR has a determinant role for driving developing $\mathrm{T}$ cells to the Foxp $3^{+} \mathrm{CD} 4^{+} \mathrm{CD} 25^{+}$Treg cell lineage and differentiation. 


\section{Introduction}

A key feature of the immune system is its ability of self-nonself discrimination, which is required for eliminating invading pathogenic microbes while maintaining immunological tolerance to self-antigen. During thymic development of $\mathrm{T}$ cells, immature thymocytes express a highly diverse repertoire of $\alpha \beta$ T-cell receptors (TCRs), including potentially harmful specificities for self-antigen. Self-reactive T cells produced in thymus are rendered self-tolerant by the mechanisms of central and peripheral tolerance. These cells are deleted in the thymus, and, when they have escaped the deletion, rendered anergic or suppressed by other T cells not to become activated or expand. Among these mechanisms of self-tolerance, accumulated evidence indicates that dominant suppression by regulatory $\mathrm{T}$ cells (Treg cells) is essential for establishing and sustaining self-tolerance and immune homeostasis.

A direct demonstration of the role of immunosuppressive $\mathrm{CD}^{+} \mathrm{T}$ cells in self-tolerance is that depletion of a $\mathrm{CD}^{+}$subpopulation from normal rodents produces autoimmune disease and the reconstitution of the depleted population suppresses the disease development. Efforts to characterize such naturally present autoimmune-suppressive population by expression levels of cell surface molecules have revealed that it constitutively expresses CD25 (IL-2 receptor a-chain) and that depletion of $\mathrm{CD} 4{ }^{+} \mathrm{CD} 25^{+} \mathrm{T}$ cells produces a variety of autoimmune diseases immunologically similar to the human counterparts [1]. This naturally arising $\mathrm{CD} 4{ }^{+} \mathrm{CD} 25^{+}$Treg population constitutes $5-10 \%$ of peripheral $\mathrm{CD} 4^{+} \mathrm{T}$ cells in normal naïve mice and humans. Depletion of $\mathrm{CD} 4{ }^{+} \mathrm{CD} 25^{+}$Treg cells also provokes immune responses to commensal bacteria in the intestine, causing inflammatory bowel disease (IBD), and evokes immune responses beneficial to the host, for example, effective tumor immunity and anti-microbial immunity. Conversely, when antigen-specific $\mathrm{CD} 25^{+} \mathrm{CD} 4^{+}$Treg cells are expanded, they are able to suppress allergy, establish tolerance to organ grafts, prevent graft-versus-host disease after bone marrow transplantation, and sustain feto-maternal tolerance. Thus, Foxp $3^{+} \mathrm{CD} 25^{+} \mathrm{CD} 4^{+}$Treg cells are capable of controlling a diverse variety of immune response whether it is physiological or pathological.

In addition to characteristic expression of cell surface molecules such as CD25, natural Treg cells specifically express the transcription factor Foxp3. Foxp3 is a master control gene for Treg development since expression of Foxp3 in normal naïve T cells converts 
them to Treg-like cells functionally and phenotypically. Genetic deficiency or dysfunction of Foxp3 is indeed causative of autoimmune disease such as type 1 diabetes, allergy, and immunopathology such as IBD in humans. Further, in the periphery, Foxp $3^{+}$Treg cells with similar immunological properties with thymus-derived Treg cells can be generated from naïve $\mathrm{T}$ cells under certain conditions.

One of the key issues in current Treg cell research is to understand at the molecular level how Foxp $3^{+}$Treg cells are produced in the thymus and periphery and how they are capable of controlling such a variety of physiological and pathological immune responses against self and non-self. Obviously Foxp $3^{+}$Treg cells bear antigen specificity, which is essential for their development in the thymus and periphery. In addition, they need to be activated by antigen via TCR to exert suppressive activity. In this review, we first summarize immunological characteristics of Treg cells and then discuss how TCR signaling contributes to the development and function of Foxp $3^{+}$Treg cells. We also review how Foxp3 operates in Treg cells.

\section{Immunobiological characteristics of Treg cells}

\section{(i) Foxp3 as a master regulator of Treg cell function}

Natural Treg cells specifically express Foxp3 [2-4]. The Foxp3 gene was first identified as a defective gene in the mouse strain Scurfy, which is an X-linked recessive mutant with lethality in hemizygous males and exhibit hyperactivation of $\mathrm{CD} 4^{+} \mathrm{T}$ cells and overproduction of proinflammatory cytokines [5]. In humans, mutations of Foxp3 result in deficiency or dysfunction of $\mathrm{CD} 4{ }^{+} \mathrm{CD} 25^{+}$Treg cells, and thus cause the disease called immune dysregulation, polyendocrinopathy, enteropathy, X-linked (IPEX) syndrome characterized by severe multi-organ autoimmune diseases, allergy, and IBD [6]. Foxp3 is preferentially expressed in $\mathrm{CD} 4^{+} \mathrm{CD} 8^{-} \mathrm{CD} 25^{+}$thymocytes and peripheral $\mathrm{CD} 4^{+} \mathrm{CD} 25^{+} \mathrm{T}$ cells in mice. It is a member of the forkhead/winged-helix family of transcription factors, containing a highly conserved C-terminal winged-helix/forkhead DNA-binding domain, a $\mathrm{C}_{2}-\mathrm{H}_{2}$ zinc finger, and a leucine zipper [7]. The N-terminal domain of Foxp3 is unique to the FOXP subfamily, and it is critical for transcriptional repression. Ectopic retroviral transduction of the Foxp 3 gene in $\mathrm{CD} 25^{-} \mathrm{CD} 4^{+} \mathrm{T}$ cells can convert them to $\mathrm{CD} 25^{+} \mathrm{CD} 4^{+}$ Treg-like cells that are able to suppress proliferation of other $\mathrm{T}$ cells in vitro and inhibit the development of autoimmune disease and IBD produced by Treg depletion [2, 3]. Foxp3 
transduction in naïve T cells up-regulates the expression of CD25 and other Treg-associated cell-surface molecules, such as cytotoxic $\mathrm{T}$ lymphocyte-associated 4 (CTLA-4) and glucocorticoid-induced TNFR-related gene (GITR), and also represses the production of IL-2, interferon $\gamma$ (IFN- $\gamma$ ), and IL-4. These characteristics are closely similar to those observed in natural Tregs. Thus, Foxp3 is so far the most reliable Treg marker with functional relevance.

\section{(ii) Foxp3-dependent suppressive functions of Treg cells}

Many possible mechanisms for Treg-mediated suppression have been proposed in the past decade $[8,9]$. The contribution of cell contact-dependent mechanisms is suggested by the in vitro inability of Tregs to suppress the proliferation of responder T cells when the two populations are separated by a semi-permeable membrane $[10,11]$. Culture supernatant of antigen-stimulated Tregs also fails to exhibit suppressive activity. Following cell contact, Treg cells may kill responder $\mathrm{T}$ cells by a granzyme-dependent or perforin-dependent mechanism or deliver a negative signal to responder $\mathrm{T}$ cells leading to inhibition of $\mathrm{T}$ cell proliferation [12-14]. In addition, there is a possibility that IL-2 nonproduction by Foxp3 ${ }^{+}$Treg cells, together with their constitutive high expression of the high-affinity IL-2 receptor (IL-2R), makes Treg cells efficiently absorb IL-2 from the vicinity, thereby contributing to the hindrance of the activation/expansion of responder T cells [15]. Modification of APC function is also involved in the suppressive mechanisms. Activated Treg cells may down-modulate the expression of CD80 and CD86 on APCs, as well as stimulate DCs to express the enzyme indoleamine 2,3-dioxygenase (IDO) [16, 17]. IDO catabolizes conversion of the essential amino acid tryptophan to kynurenine, which is toxic to $\mathrm{T}$ cells neighboring the DCs. These processes appear to be dependent on CTLA-4 molecules expressed on the Treg cell surface. Activated Tregs can also kill APCs [18].

In addition, Treg-mediated suppression involves secretion of suppressive humoral factors, such as IL-10, transforming growth factor- $\beta$ (TGF- $\beta$ ), IL-35 and galectin-1 [8, 19, 20]. Although TGF- $\beta$ and IL-10 are not required for Treg-mediated suppression in vitro, they contribute, at least in part, to in vivo suppression of IBD induced in mice by Treg depletion $[21,22]$. Furthermore, Treg cells, but not conventional $\mathrm{T}$ cells, secrete a novel inhibitory cytokine, IL-35, which is a member of the IL-12 family and a hetrodimer comprised of Ebi3 and I112a/p35 [23]. IL-35 production in Treg cells is substantially increased after the co-culture with effector $\mathrm{T}$ cells, and required for maximal Treg function in vitro and in vivo. 
Taken together, these in vivo and in vitro findings indicate that multiple mechanisms including cell-contact and factor-mediated ones may operate in Treg-mediated suppression. It remains to be determined how each one contributes to in vivo suppression under different conditions and whether there is any core mechanism which is indispensable for sustaining self-tolerance and immune homeostasis [24]. In this regard, it is worth noting that the expression of Foxp3 can confer suppressive activity to non-Treg cells. Among the molecules discussed above, Foxp3 controls the expression of IL-2, CD25, and CTLA-4 by binding to their promoters. IL-2 or CD25 deficiency or Treg-specific CTLA-4 deficiency produces fatal autoimmunity/inflammation similar to the one observed in Foxp3 deficiency. Assuming that IL-2 and its signaling via IL-2R (CD25) are mainly required for Treg survival, a CTLA-4-dependent mechanism of suppression may constitute a core mechanism of suppression in vivo [25].

\section{(iii) Requirement of TCR stimulation for Treg-mediated suppression}

$\mathrm{CD} 4{ }^{+} \mathrm{CD} 25^{+}$Treg cells require antigen stimulation via TCR to exert Treg suppressive function in vitro. Once activated by a specific antigen, Treg cells exhibit antigen-nonspecific suppression on the activation and expansion of other T cells [10]. For example, Treg cells specific for antigen A can be activated by an APC presenting antigen A; this antigen A-specific Treg cells can suppress the activation and expansion of not only antigen A-specific effector T cells but also antigen B-specific effector $\mathrm{T}$ cells recruited to the APC presenting both antigen A and B. That is, Treg cells are able to exert bystander suppression at least in vitro. Furthermore, with TCR transgenic mice, the concentration of antigenic peptide required to activate the peptide-specific Tregs to exert suppression in vitro is much lower ( $~ 100$ times) than the concentration needed for activating naïve $\mathrm{T}$ cells with the same antigen specificity [10]. This high antigen sensitivity of natural Treg cells can mainly be attributed to their high expression of accessory molecules including adhesion molecules such as leukocyte function-associated molecule-1 (LFA-1) and intercellular adhesion molecule-1 (ICAM-1), and also their "antigen-primed" or "semi-activated" state as suggested by high expression of CD44, CD25, GITR, folate receptor 4 (FR4), and CTLA-4 [26-28]. Indeed, in the presence of specific antigen, Treg cells outcompete with naïve $\mathrm{T}$ cells in forming aggregates around antigen-presenting DCs $[25,29]$. This aggregation does not occur in the absence of antigen. This means that self-antigen-specific natural Tregs can be activated even 
by B7-low immature DCs that are presenting a low amount of self-peptide (for example, derived from ingesting apoptotic cells), even if the amount of the antigen is not sufficient to activate naïve self-reactive $\mathrm{T}$ cells. This is a key property of natural Treg cells engaged in dominant self-tolerance.

\section{(iv) Cytokines: IL-2 for Treg survival and TGF- $\beta$ for their peripheral induction.}

The constitutive high-expression of CD25 is a key feature of Foxp3 ${ }^{+}$natural Treg cells [30]. In Treg cells, Foxp3 represses the transcription of $I l 2$ and activates $C d 25$, making them highly dependent on exogenous IL-2 for their maintenance in the periphery [31]. Deficiency of IL-2, CD25, or CD122 produces fatal autoimmune/inflammatory disease, which is mainly due to defective survival of natural Treg cells [32]. In humans, CD25 deficiency also exhibits severe autoimmunity and allergy resulting from deficiency or dysfunction of Foxp $3^{+}$Treg cells [33]. In the thymus, Treg development is hampered by IL-2 deficiency especially when combined with deficiency of other $\gamma_{c}$ cytokines (e.g., IL-7 and IL-15) [34, 35]. In addition, IL-2 is required for sustained expression of Foxp3 and CD25 in natural Tregs and enhances their suppressive function, at least in vitro [34, 36]. Thus, Treg development and maintenance are highly dependent on IL-2 secreted by other subsets of lymphocytes, while Treg itself suppresses IL-2 production.

Treg cells are generated in several experimental conditions, for example, by in vitro antigenic stimulation of naïve $T$ cells in the presence of TGF- $\beta$ and IL-2 [37]. In this TGF- $\beta$-dependent Treg induction in vitro, IL-6 hampers the induction [38]. Interestingly, antigen stimulation in the presence of TGF- $\beta$ and IL- 6 facilitates differentiation of naïve T cells to Th17 cells in mice [39, 40]. IL-2 on the other hand inhibits the differentiation [41]. These findings indicate that TCR stimulation in the presence of particular combinations of cytokine is able to drive naïve $\mathrm{T}$ cells to differentiate to Treg cells as well as a variety of helper T cell subsets including Th1, Th2, and Th17 cells.

\section{Cellular and molecular basis of Treg cell development and repertoire formation}

The immunological features of Foxp $3^{+}$Treg cells discussed above indicate that TCR signal, together with other signals including cytokine, is essential for their development in the thymus and periphery. TCR signal may also turn on the expression of Foxp3 in developing T cells in the thymus. 


\section{(i) Essential roles of TCR for Treg cell development}

The observation that Treg cells do not develop in $\alpha \beta T C R$ transgenic mice deficient in recombination activating gene $\left(R A G^{-/}\right)$strongly indicates that Treg cell development in the thymus requires TCR gene rearrangement at the TCR $\alpha$-chain locus and resulting TCR specificities different from the transgenic TCR specificity. The number of Foxp $3^{+}$Treg cells in $\alpha \beta T C R$ and $\beta T C R$ transgenic mice is substantially reduced, also suggesting that TCR specificity contributes to Treg cell development [26]. Moreover, a mutation in the gene encoding LAT (linker of activated T cell), a TCR proximal signal transduction molecule, abolishes the generation of Foxp $3^{+}$Tregs in the thymic and periphery while allowing the development of other $\mathrm{T}$ cells [42]. This indicates that Treg development requires a strong signal via the TCR in the thymus. Furthermore, in double-transgenic mice expressing a transgene-encoded peptide in the thymic stromal cells at a high level, the majority of $\mathrm{T}$ cells expressing transgenic $\alpha$ and $\beta$ chains specific for the peptide differentiate to $\mathrm{CD} 25^{+} \mathrm{CD} 4^{+} \mathrm{T}$ cells $[43,44]$. A recent study also showed that inactivation of Lck, which blocks their capacity to signal through their TCRs, results in abnormal Treg homeostasis characterized by impaired turnover, preferential redistribution to the lymph nodes, and loss of suppressive function [45]. Altogether, these studies indicate that the TCR signaling is essential for the development of natural Treg cells in the thymus and their various functions including migration and suppression.

In addition to the signaling via TCR, costimulatory signal is required for the control of Treg development and homeostasis. For example, CD28-deficient mice develop a reduced number of Foxp3 $^{+}$Treg cells [46]. Mice deficient in CD28 or B7-1/B7-2 on non-autoimmune-prone backgrounds display profoundly defective immune responses; however, CD28 or B7-1/B7-2 deficient mice on the diabetes-prone NOD background develop a fulminant form of diabetes [47, 48]. Exacerbation of the disease is accompanied by a dramatic decrease in the percentage of $\mathrm{CD} 4{ }^{+} \mathrm{CD} 25^{+}$Treg cells in these mice. Furthermore, the occurrence of diabetes can be suppressed in NOD-CD28 deficient mice by injection of wild-type Treg cells [49]. These findings indicate that CD28-B7 interaction is critical for thymic generation and peripheral maintenance of Treg cells.

\section{(ii) Requirement of thymic epithelial cells for Treg cell development}

Development of Treg cells relies not only on TCR signal, but also on signal from T 
cell accessory molecules interacting with thymic stromal cells. Most of Foxp $3^{+}$thymocytes are found in the thymic medulla, indicating that the differentiation of developing $\mathrm{T}$ cells to express Foxp3 occurs in the thymic medulla. At the cellular level, both medullary thymic epithelial cells (mTECs) and DCs in the thymus contribute to Treg generation/differentiation. For example, deficiency in tumor necrosis factor receptor-associated factor 6 (TRAF6) or NF-kB-inducing kinase results in the absence of mature mTECs, hampering the development of Tregs $[50,51]$. A population of mTECs ectopically expresses a set of tissue-specific antigens (TSAs), such as insulin, under the control of the Aire (autoimmune regulator) gene [52]. Interestingly, Aire-deficient mice spontaneously develop autoimmune diseases similar to those produced by Treg depletion, although Aire-deficient mice bear a normal number and apparently normal function of Foxp $3^{+}$Treg cells. It remains obscure whether Aire-expressing mTECs contribute to the formation of TCR repertoire of Foxp $3^{+}$Treg cells reactive with TSAs.

\section{(iii) TCR repertoire formation in $\mathrm{Foxp}^{+}$Treg cells}

TCR repertoires of Foxp $3^{+}$Tregs and Foxp3- conventional T cells are distinct with some overlaps as suggested by the following findings.

In TCR $\alpha \beta$ transgenic mice, which spontaneously develop $\mathrm{CD} 25^{+} \mathrm{CD} 4^{+}$Treg cells as in nontransgenic mice, Treg cells predominantly express endogenous TCR $\alpha$ chains paired with the transgenic $\beta$ chain [26]. In contrast, the majority of $\mathrm{CD} 25^{-} \mathrm{CD} 4^{+} \mathrm{T}$ cells express the TCR solely composed of transgenic $\alpha$ and $\beta$ chains. $R A G$ deficiency in these TCR transgenic mice blocks gene rearrangement at the endogenous TCR $\alpha$ chain and abrogates the development of $\mathrm{CD} 25^{+} \mathrm{CD} 4^{+}$Tregs, indicating that self-reactive TCRs utilizing endogenous $\alpha$ chains contribute to positive selection of Foxp $3^{+}$thymocytes. Similarly, in a mouse experimental allergic encephalitis (EAE) model, mice expressing an encephalatogenic $T C R$ as a transgene are protected against the development of EAE when the mice are able to rearrange the endogenous $T C R$ gene. However, these $T C R$ transgenic mice with $R A G$ deficiency developed severe disease. Moreover, in $R A G^{+/+} T C R-T g$ mice, $\mathrm{CD} 4^{+} \mathrm{CD} 25^{+}$Treg cells only develop among $\mathrm{T}$ cells that express endogenous TCR chains in addition to the transgenic TCR [53]. In these studies, restricting $\mathrm{CD}^{+} \mathrm{T}$ cells to solely express the transgenic $T C R$ inhibits the formation of an effective Treg repertoire, allowing $\mathrm{CD}^{+} \mathrm{T}$ cells expressing the transgenic $T C R$ to induce disease. 
The diversity of TCRs displayed by Treg cells versus non-Treg cells has been assessed by sequencing V $\alpha 2$-containing variable regions of the TCR $\alpha$-chain (TCR $\alpha$ ) from T cells purified from mice expressing a TCR $\beta$ transgene and a single copy of the TCR $\alpha$ locus $\left(\mathrm{Tcra}^{+-}\right)[54,55]$. In these studies, the degree of TCR repertoire diversity displayed by peripheral $\mathrm{CD} 25^{+}$and $\mathrm{CD} 25^{-} \mathrm{CD} 4^{+} \mathrm{T}$ cell subsets are comparable, but the repertoires are distinct. Furthermore, there is much similarity between thymic and peripheral TCR repertoires of $\mathrm{CD} 25^{-} \mathrm{CD} 4^{+}$conventional $\mathrm{T}$ cells, indicating that a subset of thymocytes with distinct TCR sequences is recruited to the Treg lineage during thymic development.

Additionally, a recent report has suggested the presence of two subsets of peripheral Foxp $^{+}$Treg cells differing in the level of Foxp3 expression and the TCR repertoire [56]. Treg cells expressing a high level of Foxp3 and TCRs not used by naïve CD4 ${ }^{+} \mathrm{T}$ cells exhibit a stable suppressor phenotype and dominate the peripheral Treg population. The second Treg subset, expressing a lower level of Foxp3 and using TCRs shared with naïve CD4 ${ }^{+} \mathrm{T}$ cells, constitute a small fraction of Treg cells and have a versatile phenotype and may down-regulate Foxp3 expression. Thus, there appears to be a correlation between the level of Foxp3 expression and functional stability of Treg cells.

Based on these observations, it is likely that TCR engagement by a high-affinity self-ligand initiates signaling cascades that induce Foxp3 expression, which further drives thymocytes to the Treg cell lineage. Furthermore, several lines of evidence indicate that the availability of a "niche" for cognate antigen is important for the decision of Treg cell fate, generation or elimination in thymus $[57,58]$. The precise mechanism of this selection and differentiation of Foxp $3^{+}$Treg cells and stable maintenance of Foxp3 expression in Treg cells remain to be elucidated.

\section{(iv) Another master for Treg cell development?}

Although Foxp3 is recognized as the master of Treg development, recent studies suggest that Foxp3 is not required for the initial commitment of Treg cell lineage in the thymus. Using reporter mice in which the Foxp3 coding region is replaced by a green fluorescent protein (GFP) reporter, two groups have demonstrated that GFP-positive thymocytes, which do not express the Foxp3 protein, show some characteristics of the Treg phenotype including the expression of CD25, GITR and CTLA-4, although they are not suppressive in vitro $[59,60]$. This indicates that thymocytes are driven to the Treg lineage 
without Foxp3, and that once the Foxp3 gene is transcribed, Foxp3 may stabilize and sustain the Treg phenotype and confer suppressive activity. In addition, insulin-like 7, galectin-1, granzyme B and helios genes are found to be specifically expressed in natural Treg, but independent of Foxp3 expression; for example, ectopic Foxp3 expression in conventional naïve $\mathrm{T}$ cells fails to up- or down-regulate the expression of these genes in contrast with Foxp3-controlled CD25, CTLA-4, GITR and other genes [59, 61, 62]. Furthermore, a cross-sectional analysis of the Treg cell signature in Treg-like cells generated under a number of conditions with or without Foxp3 has revealed that much of the Treg cell signature is not ascribable to Foxp3 [62]. These findings indicate that a higher level of regulation, which is independent of Foxp3, might exist in the Treg lineage commitment. Thus, it is intriguing to determine what mechanisms define the Treg differentiation program and turn on Foxp3 gene expression in developing thymocytes.

\section{Molecular basis of Foxp3 induction and function}

\section{(i) Factors required for Foxp3 induction}

Foxp3 induction in Treg cells is controlled via a variety of signaling pathways involving TCR, IL-2, signal transducers and activators of transcription (STAT), Smad, TGF- $\beta$, phosphatidylinositol 3-kinase (PI3K)/Akt/mTOR, and Notch. Upon TCR engagement with self-peptide/MHC ligands, Foxp3 expression is controlled by transcription factors that can bind to the promoter or enhancer regions of the Foxp3 gene. Within the 5' flanking region of the Foxp 3 transcription start site, there are several important transcription factor-binding sites, including those for AP-1 and NFAT, along with typical sites of eukaryotic promoters including TATA and CAAT boxes. This region acts as the promoter for Foxp 3 transcription and is referred to as the proximal promoter region, which is highly conserved over many species. Recent studies have shown that these NFAT and AP-1 binding sites positively regulate the transcriptional activation of the Foxp3 gene in response to TCR stimulation. NFAT and Smad3 binding sites also locate in an enhancer region of the Foxp3 gene [63]. Histone acetylation is observed in this enhancer region in mature natural Foxp $3{ }^{+} \mathrm{CD} 4{ }^{+} \mathrm{CD} 25^{+}$ Treg cells and is also induced by TGF- $\beta$ coupled with anti-CD3 and anti-CD28 stimulation in primary $\mathrm{CD}^{+} \mathrm{T}$ cells. NFAT and Smad3 cooperate to induce Foxp3 gene expression and NFAT maintains activity of the enhancer and consequently Foxp3 gene expression. Further, induction of Foxp3 expression is blocked by the Smad3 inhibitor SIS3 [63]. Thus, NFAT and 
Smad3 are key transcription factors that induce the expression of the Foxp3 gene and govern the differentiation of $\mathrm{CD} 4^{+} \mathrm{CD} 25^{+}$Treg cells.

Moreover, a TCR-responsive enhancer found in the Foxp3 first intron contains cyclic-AMP response element binding protein (CREB)/activating transcription factor (ATF) site overlapping a $\mathrm{CpG}$ island [64]. Methylation of this island inversely correlates with CREB binding and Foxp3 expression. TGF- $\beta$, which induces Foxp $3^{+}$Treg cells from naïve CD $4^{+} \mathrm{T}$ cells, decreases methylation of the $\mathrm{CpG}$ island and increases Foxp3 expression. A dominant-negative CREB construct that can inhibit not only CREB but also ATF1 and ATF2 diminishes PMA/ionomycin induced Foxp3 expression in a dose-responsive manner when a Foxp3 first intron-containing construct is used in reporter assay [64]. Thus, TCR-induced Foxp3 expression in Treg cells is controlled both by sequence-specific binding of CREB/ATF and by DNA demethylation of a $\mathrm{CpG}$ island.

Besides TCR signaling, a variety of signaling pathways controls the expression of Foxp3. One of them is signaling from IL-2 via the IL-2 receptor. This signaling is generally dependent on STAT5. Consensus sites for STAT5 binding are found in the proximal promoter and intronic regions of Foxp3. However, only the proximal promoter conserved region shows binding with STAT5, dependent on IL-2R signaling.

The vitamin A metabolite retinoic acid (RA) also induces de novo generation of Foxp $3^{+}$Treg cells. In the presence of TGF- $\beta$, RA facilitates the differentiation of naïve $\mathrm{T}$ cells to Foxp $3^{+}$Treg cells [65-67]; and all-trans-retinoic-acid induces histone $\mathrm{H} 4$ acetylation at the Foxp3 locus. However, there is no report showing that activated RA receptor directly control the expression of Foxp3. Thus far, RA induction of Treg cells from naïve $\mathrm{CD} 4{ }^{+} \mathrm{T}$ cells can be attributed to enhanced TGF- $\beta$ driven phosphorylation of SMAD3 along with the inhibition of IL-6 and IL-23 receptor expression [68].

Together, these findings indicate that several diverse intrinsic and extrinsic signals regulate Foxp3 expression, and that TCR signaling can be a critical factor for Foxp3 induction.

\section{(ii) Foxp3-dependent control of Treg function}

Through genome-wide analysis combining chromatin immunoprecipitation with DNA microarray, Foxp3 binds to the regions for $\sim 700$ genes, and a large number of Foxp3-bound genes are up- or down-regulated in Foxp $3^{+}$cells [69]. The study suggests that 
Foxp3 acts as both a transcriptional activator and repressor. In another study, Foxp3 binds to forkhead motifs of about 1,100 genes in PMA/inomycin stimulated T cell hybridomas [70]. Most of the promoters occupied by Foxp3 in stimulated $\mathrm{T}$ cells are also occupied in unstimulated cells. However, the intensity of Foxp3 binding considerably increases at some promoters upon PMA/ionomycin stimulation. These findings are in line with observations that suppressive function of Tregs requires TCR engagement. Foxp3 binding genes are enriched for the genes involved in signaling pathways, cell communication, and transcriptional regulation, including those encoding cell surface molecules (e.g. Il2ra, Ctla4, and FasL), TCR signaling-related molecules (e.g. Zap70 and Ptpn22), transcription factors (e.g. Foxp3 itself), cytokines (e.g. Il2), enzymes for cell metabolism (e.g. Pde3b), and microRNAs (e.g. $m i R-155)$. Altogether, these genome-wide studies clearly show that Foxp3 controls a variety of physiological processes, and functions as an activator as well as a repressor of transcription depending on the target genes.

Foxp $3^{+}$Treg can also functionally differentiate to acquire an ability to control Th1, Th2 or Th17 type immune responses. For example, a fraction of Foxp3 ${ }^{+}$natural Treg expresses the Th1-specifying transcription factor T-bet in response to IFN- $\gamma$ [71]. They up-regulate CXCR3, a T-bet-controlled chemokine receptor, and then guide themselves to type 1 inflammation sites. In addition, Foxp3 directly controls the expression of the transcription factor interferon regulatory factor-4 (IRF-4), which is required for Th2 differentiation [72]. Interestingly, Treg-specific deletion of IRF-4 impairs the control of Th2, but not Th1 immune responses, resulting in spontaneous development of Th2 type inflammation. Moreover, a recent study shows that Foxp3 is associated with the transcriptionally active, phosphorylated form of Stat3, which is a critical transcription factor for Th17 differentiation [73]. Stat3 activation-dependent association with Foxp3 transcriptional complexes may result in modulation of Stat3-dependent gene expression in part through Stat3-dependent recruitment of Foxp3. Thus, the activation of Stat3 in Tregs endows them with the ability to suppress Th17 responses through increased expression of a subset of suppressor molecules as well as cytokine and chemokine receptors. In aggregates, Foxp3 modifies a transcriptional control of the lineage specific transcription factors and acquire an ability to control specific immune responses. Conversely, lineage specific transcription factors, such as T-bet, IRF-4 and Stat3, may facilitate Treg cell ability to suppress the corresponding type of the immune response. 


\section{(iii) Foxp3-interacting factors for the Foxp3-dependent transcription}

Foxp3-dependent transcriptional regulation also requires other transcription factors along with chromatin-remodeling factors, histone deacetylase, and histone acetyltransferase, to perform accurate transcriptional regulation in Tregs [74]. To examine the Foxp3-dependent regulation, attempts have been made to find the molecules associated with Foxp3. These studies have revealed that Foxp3 interacts with the transcription factor NFAT (nuclear factor of activated T cells), AML1 (acute myeloid leukemia-1)/Runx1 (runt-related transcription factor 1), ROR $\gamma$ t (RAR-related orphan receptor C) and Eos (Ikaros family zinc finger protein, subfamily 1A, member 4) [75-78]. Moreover, by MS/Qstar spectrometric analysis of the immunoprecipitated Foxp3 complex in ectopically Foxp3-expressing T cells, Foxp3 is shown to form a large transcriptional complex with several chromatin remodeling factors including SWI/SNF related, matrix associated, actin dependent regulator of chromatin, subfamily a, member 4 (BRG1); Methyl-CpG binding domain protein 3 (MBD3); and RuvB-like DNA helicases TIP49a and TIP49b; and ATP-dependent DNA helicase II 70kDa subunit Ku70 [74]. Those chromatin remodeling factors co-fractionate precisely with Foxp3 in a large molecular weight complex. Transcriptional control exerted by Foxp3 also involves HATs, such as TIP60, and HDACs, such as HDAC7 and HDAC9. Acetylation of Foxp3 by TIP60 enhances the binding of Foxp3 to the $I l 2$ promoter and augments the repression of $I l 2$ [79].

Thus, transcription complex containing Foxp3 might be a key to address the complexity of the expression of Treg-associated molecules, suppressive functions, and stability of Treg lineage. In the following sections, we will focus on the transcription factors NFAT, Runx1, ROR $\gamma \mathrm{t}$ and Eos, all of which are shown to interact with Foxp3, and appear to play specific roles for Treg cells.

\section{(a) NFAT}

The activity of NFAT is controlled by calcium and the calcium-dependent protein phosphatase calcineurin. In resting cells, these proteins are heavily phosphorylated and reside in the cytosol. TCR engagement results in the activation of the calmodulin-dependent phosphatase calcineurin, which binds to the N-terminus of NFAT and dephosphorylates multiple serine residues in the NFAT protein [80, 81]. After dephosphorylation, NFAT proteins translocate into the nucleus and initiate the transcription of NFAT-target genes [82]. 
Activated NFAT forms a complex with AP-1 and NF-kB and promotes the expression of IL2, IL4, Ctla4, and other genes in conventional $\mathrm{T}$ cells [83]. Thus, NFAT contribute to the activation of $\mathrm{T}$ cells and their differentiation to effector $\mathrm{T}$ cells.

A recent study has shown that Foxp3 can associate with NFAT, and the interaction between Foxp3 and NFAT is dependent upon their cooperative binding to DNA [75]. Crystal structure of a complex containing the forkhead domain of Foxp2 and the DNA binding domain of NFAT1, demonstrates that Foxp proteins can associate with NFAT transcription factors in the transcriptional complexes [84]. These complexes bind to NFAT:AP-1 composite sites on the $I L-2$ promoter and likely displace NFAT:AP1 complexes, thereby directly repressing $I L-2$ transcription. Amino acid substitutions of Foxp3 that disrupt the Foxp3-NFAT interaction impair the ability of Foxp3 to repress Il2, activate Ctla4 and Cd25, and confer suppressive activity [84]. Thus, the interaction between NFAT and Foxp3 is essential for the function of Foxp3. In fact, mice deficient in both NFATc2 and NFATc3 spontaneously develop severe lymphoadenopathy and selective activation of Th2 cells, suggesting that the deficiency might disrupt the function of Foxp3 and consequently impair Treg function [85].

\section{(b) Runx1}

Runx proteins are transcription factors that have crucial roles for the development of many tissues and the immune system, and form a family of evolutionarily conserved heterodimeric transcription factors [86]. Runx complexes are composed of unique DNA-binding $\alpha$-subunits, Runx1, Runx2, or Runx3, which are homologues of the Drosophila runt gene. To form the functional complexes, they pair with the non-DNA binding subunit core-binding factor $\beta, \operatorname{Cbf} \beta$, which has been shown to stabilize the interaction of Runx proteins with DNA. Targeted deletion of Runx subunits has revealed that Runx family proteins possess distinct roles for development. For example, Runxl deletion is shown to be required for haemotopoiesis [87], and Runx3 for neurogenesis [88].

In naïve T cells, Runx 1 constitutively binds to the $I l 2$ promoter at the site upstream to the binding sites of NFAT and AP-1 [76]. Upon T cell activation, Runx1 may act as an organizing factor that facilitates the assembly of active transcriptional complex on the $I l 2$ promoter. On the other hand, in Treg cells, Runx1 has been shown to bind to Foxp3 at its $\mathrm{N}$-terminal region in Tregs and play a role for Foxp3-mediated transcriptional regulation. Disrupting the binding between Foxp3 and Runx1 impairs the Foxp3-dependent suppression 
of IL-2 production and attenuates suppressive activity. Knockdown of Runx1 in natural Tregs abrogates their suppressive activity. These results suggest that the interaction between Runx1 and Foxp3 is essential for Treg function in vitro. Furthermore, Kitoh et al. have recently demonstrated that Treg-specific ablation of $C b f \beta$ or Runx1, but not Runx3, causes autoimmune/inflammatory disease in mice [89]. Since the $\operatorname{Cbf} \beta$ subunit acts as a binding partner for all Runx proteins, targeted inactivation of $C b f \beta$ expression abrogates the activity of all Runx complexes [90,91]. Treg-specific deficiency of $C b f \beta$ induces lymphoproliferation, autoimmune disease, and hyperproduction of IgE. Similar Treg cell-specific gene targeting has revealed that the Runx and Cbf $\beta$ complex is required for the maintenance of Foxp3 mRNA and protein expression in Treg cells [92]. Indeed, Foxp3 expression in natural Treg cells correlates well with the binding of Runx/Cbf $\beta$ to regulatory elements within the Foxp3 locus. In addition, $C b f \beta$-deleted Treg cells exhibit impaired suppressive function in vitro and in vivo, with altered gene expression profiles including attenuated expression of Foxp3. Interestingly, Runx-binding site-dependent transactivation is observed only under activated condition, and not under unstimulated condition. These observations suggest that the Runx complex regulates constitutive Foxp3 expression rather than by transactivating the Foxp3 gene. In addition, Runx promotes de novo expression of Foxp3 during inducible Treg cell differentiation in vitro, and a dominant-negative Runt DNA binding domain antagonized the de novo Foxp3 expression [93]. It has been shown that Runx $1 / \mathrm{Cbfb}$ is not only a conventional transcriptional activator but also plays a critical role for properly guiding and forming Foxp3-containing transcriptional complex required for Foxp3-dependent transcription at specific DNA loci.

In line with the possible contribution of Runx1 to the Foxp3-mediated Treg function, there are some reports indicating the importance of Runx family in autoimmunity. Runx3-deficinet mice spontaneously develop IBD and hyperplastic gastritis-like lesions, which are immunologically similar to those produced by Treg depletion [94, 95]. Disease-associated regulatory single nucleotide polymorphisms (SNPs) affecting the consensus sites for Runx1 are associated with genetic susceptibility to several autoimmune diseases including systemic lupus erythematosus, rheumatoid arthritis, and psoriasis [96-98]. In addition, a SNP in the Runx1 gene itself is strongly associated with rheumatoid arthritis [98]. It is thus likely that genetic anomalies of Runx family may contribute to the development of autoimmune disease and other immunological diseases by means of affecting 
Treg-mediated immune regulation.

\section{(c) ROR $\gamma \mathrm{t}$}

Foxp3 also appear to interact with ROR $\gamma \mathrm{t}$, a key transcription factor for the differentiation of naïve $\mathrm{T}$ cells to Th17 cells characterized by the production of IL-17A, IL-17F, IL-21, and IL-22 [77]. Th17 cells play a key effector part in autoimmune diseases, elimination of extracellular bacteria, and cancer [99-101]. ROR $\gamma$ t-mediated IL-17A promoter activation is suppressed by forced expression of Foxp3, and Foxp3 directly interacts with ROR $\gamma$ t through exon2 region of Foxp3. Thus, the interaction between Foxp3 and ROR $\gamma \mathrm{t}$ might be important for the suppression of Th17 and polarization into induced Tregs. While Th17 differentiation of naïve T cells is initiated by IL- 6 and TGF- $\beta$ [39, 40, 102], TGF- $\beta$ also drives the conversion of naïve $\mathrm{T}$ cells to Foxp $3^{+}$Treg cells [103]. This suggests that the presence or absence of proinflammatory cytokines might lead to opposing immune consequences induced by TGF- $\beta$, and the interaction between ROR $\gamma \mathrm{t}$ and Foxp3 may be involved in the regulation of the Th17-Treg balance.

\section{(d) Eos}

One important feature of Treg cells is selective gene silencing of cytokine genes such as IL-2 and IFN- $\gamma$. It has been shown recently that Eos, a member of the Ikaros family, as a critical mediator of Foxp3-dependent gene silencing in Tregs [78]. The Ikaros family consists of zinc finger type transcription factors including Ikaros, Aiolos, Helios, and Eos. Some of them are expressed in lymphocytes and have been implicated in controlling lymphoid development. These proteins contain two characteristic clusters of zinc fingers, an N-terminal domain important for DNA recognition, and a C-terminal domain that mediates homo- and heterodimeric associations between family members. Eos can interact with Foxp3 and induces chromatin modifications that result in gene silencing in Treg cells. Knockdown of Eos in Treg cells abrogates their ability to suppress immune responses, suggesting critical role of Eos in Treg programming. Interestingly, Eos is involved in the Foxp3-dependent gene repression, but not in the activation, suggesting that Foxp3 suppresses gene expression through its interaction with Eos. Eos also interacts with C-terminal binding protein-1 (CtBP1), which has been shown to suppress transcription by affecting histone methylation and acetylation [104]. Thus, CtBP1 is implicated as a key repressor of Eos-mediated gene 
expression as a component of corepressor complexes, and the complexes containing Eos, CtBP1 and Foxp3 may control the epigenetic status of the Foxp3-target genes.

\section{(iv) Epigenetic control of Treg cells}

Treg cells show hypoproliferation upon TCR stimulation in vitro, whereas natural Treg cells are continuously proliferating in vivo presumably through recognition of self-antigen and commensal microbes [31, 105]. Compared to naïve $\mathrm{T}$ cells, Treg cells specifically and continuously express a set of genes, such as Il2ra (CD25), Ctla4 and Gitr. The permanent and heritable gene expression profiles of proliferating Treg cells may be maintained by epigenetic program.

Molecular mechanisms of epigenetic programming include selective demethylation of $\mathrm{CpG}$ motifs and histone modifications. Complete demethylation of $\mathrm{CpG}$ motifs are found in the evolutionarily conserved region of the Foxp 3 gene in $\mathrm{CD} 4{ }^{+} \mathrm{CD} 25^{+} \mathrm{Foxp} 3^{+}$Tregs, but not in naïve $\mathrm{CD} 4^{+} \mathrm{CD} 25^{-} \mathrm{T}$ cells. Partial DNA demethylation is already found within developing Foxp $3^{+}$thymocytes; however, Tregs induced by TGF- $\beta$ in vitro display only incomplete demethylation [106]. It suggests that a more complete $\mathrm{CpG}$ demethylation may be required for a stable Foxp3 expression. In addition, naïve T cells in humans readily express Foxp3 upon TCR stimulation, although the expression is generally much lower and more transient than in natural Tregs, suggesting that incomplete demethylation of the Foxp3 gene affects Foxp3 expression levels and its sustained expression. Consistent with these findings, demethylation induced by 5-azacytidine in human NK cells leads to induction of Foxp3 [107], and deficiency of DNA methyltransferase 1 (Dnmt1) induces enhancement of Foxp3 expression [108]. Thus, constitutive expression of Foxp3 in natural Tregs is controlled by DNA methylation of CpG islands in the Foxp3 gene, and control of DNA methylation at the Foxp3 locus is essential for establishing Treg cell lineage.

Apart from inheritance of methylated $\mathrm{CpG}$ residues in genomic DNA, parental histone molecules can also divide and be transmitted to the progeny cells. TCR stimulation induces H3-K4 di- and tri-methylation at the Foxp3 promoter and intronic enhancer regions after 18 hours of stimulation of naïve $\mathrm{CD}^{+} \mathrm{T}$ cells. This is in line with the observations that Foxp3 expression in $\mathrm{CD}^{+} \mathrm{T}$ cells is controlled by TCR signaling, and the Foxp 3 promoter and enhancer are also H3-K4 methylated in Tregs. Therefore, the TCR stimulation may initially affect the histone code of the Foxp3 gene, thereby leading to the establishment of 
epigenetic status of Treg cells.

Moreover, demethylation of the Foxp3 promoter region and the $\mathrm{CpG}$ island in the enhancer is important for the induction of Foxp3. Demethylation of the regions is controlled, at least in part, by signaling from TGF- $\beta$ and TCR. The finding is in line with the observation that Foxp 3 gene expression can be readily induced in $\mathrm{CD} 4^{+} \mathrm{CD} 25^{-} \mathrm{T}$ cells by stimulation with TGF- $\beta$, anti-CD3 and anti-CD28. A TGF- $\beta$ response element, however, has not been identified in the Foxp3 gene or in surrounding regions, suggesting that TGF- $\beta$ may modulate expression profiles of factors related to epigenetic control. The importance of TCR signaling in Foxp3 induction is also shown by using a genetic model of DNA methyltransferase 1 (Dnmt1) deficiency. In Dnmt1 knockout mice, TCR stimulation can induce Foxp3 expression at a high level [108]. Moreover, in the absence of Dnmt1, Foxp3 induction in thymic and peripheral Foxp3-negative T cells is maximized upon TCR stimulation, and the provision of TGF- $\beta$ is dispensable for Foxp3 expression. These observations suggest that the TCR signal is sufficient for transcriptional activation of Foxp3 in the absence of maintenance DNA methylation.

\section{Concluding remarks}

Treg cells have been shown to suppress a variety of physiological and pathological immune responses through multiple mechanisms. Over the last decade, considerable progress has been made in elucidating molecular mechanisms underlying Treg development and differentiation. A key finding for understanding Treg development and function at the molecular level is the identification of Foxp3 as a hallmark of this population of suppressor cells. Since Foxp3 can confer Treg suppressive activity to conventional $\mathrm{CD}^{+} \mathrm{T}$ cells, Foxp3-dependent regulation and Foxp3 induction itself are expected to be appropriate targets for the manipulation of Treg activities. In addition, TCR signaling plays prominent roles for the differentiation and selection of Treg cells, hence the formation of their TCR repertoire. Impairment or augmentation of Foxp3-dependent regulation or TCR signaling can alter the balance between Treg and effector T cells, leading to impaired peripheral self-tolerance and immune homeostasis. Pharmacological treatments that aim to modulate the balance between Treg and effector $\mathrm{T}$ cells will provide the novel therapeutic strategies in the treatment of immunological diseases. 


\section{Acknowledgements}

The authors have no conflicting financial interests. We thank Atsushi Tanaka for critically reading the manuscript. This work was supported by grants-in-aids from the Ministry of Education, Sports and Culture and the Ministry of Human Welfare of Japan. 


\section{References}

1. Sakaguchi S, Wing K, and Miyara M (2007) Regulatory T cells - a brief history and perspective. Eur J Immunol 37 Suppl 1:S116-23

2. Hori S, Nomura T, and Sakaguchi S (2003) Control of regulatory T cell development by the transcription factor Foxp3. Science 299(5609):1057-61

3. Fontenot JD, Gavin MA, and Rudensky AY (2003) Foxp3 programs the development and function of CD4+CD25+ regulatory T cells. Nat Immunol 4(4):330-6

4. Khattri R, Cox T, Yasayko SA, and Ramsdell F (2003) An essential role for Scurfin in CD4+CD25+ T regulatory cells. Nat Immunol 4(4):337-42

5. Brunkow ME, Jeffery EW, Hjerrild KA, Paeper B, Clark LB, Yasayko SA, Wilkinson JE, Galas D, Ziegler SF, and Ramsdell F (2001) Disruption of a new forkhead/winged-helix protein, scurfin, results in the fatal lymphoproliferative disorder of the scurfy mouse. Nat Genet 27(1):68-73

6. Ochs HD, Ziegler SF, and Torgerson TR (2005) FOXP3 acts as a rheostat of the immune response. Immunol Rev 203:156-64

7. Ziegler SF (2006) FOXP3: of mice and men. Annu Rev Immunol 24:209-26

8. Shevach EM (2009) Mechanisms of foxp3+ T regulatory cell-mediated suppression. Immunity 30(5):636-45

9. Sakaguchi S, Wing K, Onishi Y, Prieto-Martin P, and Yamaguchi T (2009) Regulatory T cells: how do they suppress immune responses? Int Immunol 21(10):1105-11

10. Takahashi T, Kuniyasu Y, Toda M, Sakaguchi N, Itoh M, Iwata M, Shimizu J, and Sakaguchi S (1998) Immunologic self-tolerance maintained by CD25+CD4+ naturally anergic and suppressive $\mathrm{T}$ cells: induction of autoimmune disease by breaking their anergic/suppressive state. Int Immunol 10(12):1969-80

11. Thornton AM and Shevach EM (1998) CD4+CD25+ immunoregulatory T cells suppress polyclonal $\mathrm{T}$ cell activation in vitro by inhibiting interleukin 2 production. $\mathrm{J}$ Exp Med 188(2):287-96

12. Gondek DC, Lu LF, Quezada SA, Sakaguchi S, and Noelle RJ (2005) Cutting edge: contact-mediated suppression by $\mathrm{CD} 4+\mathrm{CD} 25+$ regulatory cells involves a granzyme B-dependent, perforin-independent mechanism. J Immunol 174(4):1783-6

13. Cao X, Cai SF, Fehniger TA, Song J, Collins LI, Piwnica-Worms DR, and Ley TJ 
(2007) Granzyme B and perforin are important for regulatory $\mathrm{T}$ cell-mediated suppression of tumor clearance. Immunity 27(4):635-46

14. Bopp T, Becker C, Klein M, Klein-Hessling S, Palmetshofer A, Serfling E, Heib V, Becker M, Kubach J, Schmitt S, Stoll S, Schild H, Staege MS, Stassen M, Jonuleit H, and Schmitt E (2007) Cyclic adenosine monophosphate is a key component of regulatory T cell-mediated suppression. J Exp Med 204(6):1303-10

15. Pandiyan P, Zheng L, Ishihara S, Reed J, and Lenardo MJ (2007) CD4+CD25+Foxp3+ regulatory $\mathrm{T}$ cells induce cytokine deprivation-mediated apoptosis of effector CD4+ T cells. Nat Immunol 8(12):1353-62

16. Oderup C, Cederbom L, Makowska A, Cilio CM, and Ivars F (2006) Cytotoxic T lymphocyte antigen-4-dependent down-modulation of costimulatory molecules on dendritic cells in CD4+ CD25+ regulatory T-cell-mediated suppression. Immunology 118(2):240-9

17. Grohmann U, Orabona C, Fallarino F, Vacca C, Calcinaro F, Falorni A, Candeloro P, Belladonna ML, Bianchi R, Fioretti MC, and Puccetti P (2002) CTLA-4-Ig regulates tryptophan catabolism in vivo. Nat Immunol 3(11):1097-101

18. Zhao DM, Thornton AM, DiPaolo RJ, and Shevach EM (2006) Activated CD4+CD25+ T cells selectively kill B lymphocytes. Blood 107(10):3925-32

19. Tang Q and Bluestone JA (2008) The Foxp3+ regulatory T cell: a jack of all trades, master of regulation. Nat Immunol 9(3):239-44

20. Vignali DA, Collison LW, and Workman CJ (2008) How regulatory T cells work. Nat Rev Immunol 8(7):523-32

21. Asseman C, Mauze S, Leach MW, Coffman RL, and Powrie F (1999) An essential role for interleukin 10 in the function of regulatory $\mathrm{T}$ cells that inhibit intestinal inflammation. J Exp Med 190(7):995-1004

22. Read S, Malmstrom V, and Powrie F (2000) Cytotoxic T lymphocyte-associated antigen 4 plays an essential role in the function of $\mathrm{CD} 25(+) \mathrm{CD} 4(+)$ regulatory cells that control intestinal inflammation. J Exp Med 192(2):295-302

23. Collison LW, Workman CJ, Kuo TT, Boyd K, Wang Y, Vignali KM, Cross R, Sehy D, Blumberg RS, and Vignali DA (2007) The inhibitory cytokine IL-35 contributes to regulatory T-cell function. Nature 450(7169):566-9

24. Sakaguchi S, Wing K, and Yamaguchi T (2009) Dynamics of peripheral tolerance and 
immune regulation mediated by Treg. Eur J Immunol 39(9):2331-6

25. Wing K, Onishi Y, Prieto-Martin P, Yamaguchi T, Miyara M, Fehervari Z, Nomura T, and Sakaguchi S (2008) CTLA-4 control over Foxp3+ regulatory T cell function. Science 322(5899):271-5

26. Itoh M, Takahashi T, Sakaguchi N, Kuniyasu Y, Shimizu J, Otsuka F, and Sakaguchi S (1999) Thymus and autoimmunity: production of CD25+CD4+ naturally anergic and suppressive $\mathrm{T}$ cells as a key function of the thymus in maintaining immunologic self-tolerance. J Immunol 162(9):5317-26

27. Takahashi T, Tagami T, Yamazaki S, Uede T, Shimizu J, Sakaguchi N, Mak TW, and Sakaguchi S (2000) Immunologic self-tolerance maintained by CD25(+)CD4(+) regulatory $\mathrm{T}$ cells constitutively expressing cytotoxic $\mathrm{T}$ lymphocyte-associated antigen 4. J Exp Med 192(2):303-10

28. Yamaguchi T, Hirota K, Nagahama K, Ohkawa K, Takahashi T, Nomura T, and Sakaguchi S (2007) Control of immune responses by antigen-specific regulatory $\mathrm{T}$ cells expressing the folate receptor. Immunity $27(1): 145-59$

29. Onishi Y, Fehervari Z, Yamaguchi T, and Sakaguchi S (2008) Foxp3+ natural regulatory $\mathrm{T}$ cells preferentially form aggregates on dendritic cells in vitro and actively inhibit their maturation. Proc Natl Acad Sci U S A 105(29):10113-8

30. Sakaguchi S, Sakaguchi N, Asano M, Itoh M, and Toda M (1995) Immunologic self-tolerance maintained by activated $\mathrm{T}$ cells expressing IL-2 receptor alpha-chains (CD25). Breakdown of a single mechanism of self-tolerance causes various autoimmune diseases. J Immunol 155(3):1151-64

31. Setoguchi R, Hori S, Takahashi T, and Sakaguchi S (2005) Homeostatic maintenance of natural Foxp3(+) CD25(+) CD4(+) regulatory $\mathrm{T}$ cells by interleukin (IL)-2 and induction of autoimmune disease by IL-2 neutralization. J Exp Med 201(5):723-35

32. Malek TR and Bayer AL (2004) Tolerance, not immunity, crucially depends on IL-2. Nat Rev Immunol 4(9):665-74

33. Caudy AA, Reddy ST, Chatila T, Atkinson JP, and Verbsky JW (2007) CD25 deficiency causes an immune dysregulation, polyendocrinopathy, enteropathy, $\mathrm{X}$-linked-like syndrome, and defective IL-10 expression from CD4 lymphocytes. J Allergy Clin Immunol 119(2):482-7

34. Fontenot JD, Rasmussen JP, Gavin MA, and Rudensky AY (2005) A function for 
interleukin 2 in Foxp3-expressing regulatory T cells. Nat Immunol 6(11):1142-51

35. Vang KB, Yang J, Mahmud SA, Burchill MA, Vegoe AL, and Farrar MA (2008) IL-2, -7 , and -15 , but not thymic stromal lymphopoeitin, redundantly govern CD4+Foxp3+ regulatory T cell development. J Immunol 181(5):3285-90

36. Shevach EM, DiPaolo RA, Andersson J, Zhao DM, Stephens GL, and Thornton AM (2006) The lifestyle of naturally occurring CD4+ CD25+ Foxp3+ regulatory T cells. Immunol Rev 212:60-73

37. Curotto de Lafaille MA and Lafaille JJ (2009) Natural and adaptive foxp3+ regulatory T cells: more of the same or a division of labor? Immunity 30(5):626-35

38. Stockinger B and Veldhoen M (2007) Differentiation and function of Th17 T cells. Curr Opin Immunol 19(3):281-6

39. Veldhoen M, Hocking RJ, Atkins CJ, Locksley RM, and Stockinger B (2006) TGFbeta in the context of an inflammatory cytokine milieu supports de novo differentiation of IL-17-producing T cells. Immunity 24(2):179-89

40. Bettelli E, Carrier Y, Gao W, Korn T, Strom TB, Oukka M, Weiner HL, and Kuchroo VK (2006) Reciprocal developmental pathways for the generation of pathogenic effector TH17 and regulatory T cells. Nature 441(7090):235-8

41. Laurence A, Tato CM, Davidson TS, Kanno Y, Chen Z, Yao Z, Blank RB, Meylan F, Siegel R, Hennighausen L, Shevach EM, and O'Shea J J (2007) Interleukin-2 signaling via STAT5 constrains T helper 17 cell generation. Immunity 26(3):371-81

42. Koonpaew S, Shen S, Flowers L, and Zhang W (2006) LAT-mediated signaling in CD4+CD25+ regulatory T cell development. J Exp Med 203(1):119-29

43. Jordan MS, Boesteanu A, Reed AJ, Petrone AL, Holenbeck AE, Lerman MA, Naji A, and Caton AJ (2001) Thymic selection of CD4+CD25+ regulatory T cells induced by an agonist self-peptide. Nat Immunol 2(4):301-6

44. Kawahata K, Misaki Y, Yamauchi M, Tsunekawa S, Setoguchi K, Miyazaki J, and Yamamoto $\mathrm{K}$ (2002) Generation of $\mathrm{CD} 4(+) \mathrm{CD} 25(+)$ regulatory $\mathrm{T}$ cells from autoreactive $\mathrm{T}$ cells simultaneously with their negative selection in the thymus and from nonautoreactive $\mathrm{T}$ cells by endogenous TCR expression. $\mathrm{J}$ Immunol 168(9):4399-405

45. Kim JK, Klinger M, Benjamin J, Xiao Y, Erle DJ, Littman DR, and Killeen N (2009) Impact of the TCR signal on regulatory T cell homeostasis, function, and trafficking. 
PLoS One 4(8):e6580

46. Tai X, Cowan M, Feigenbaum L, and Singer A (2005) CD28 costimulation of developing thymocytes induces Foxp3 expression and regulatory T cell differentiation independently of interleukin 2. Nat Immunol 6(2):152-62

47. Salomon B, Lenschow DJ, Rhee L, Ashourian N, Singh B, Sharpe A, and Bluestone JA (2000) B7/CD28 costimulation is essential for the homeostasis of the CD4+CD25+ immunoregulatory $\mathrm{T}$ cells that control autoimmune diabetes. Immunity 12(4):431-40

48. Lenschow DJ, Herold KC, Rhee L, Patel B, Koons A, Qin HY, Fuchs E, Singh B, Thompson CB, and Bluestone JA (1996) CD28/B7 regulation of Th1 and Th2 subsets in the development of autoimmune diabetes. Immunity 5(3):285-93

49. Tang Q, Henriksen KJ, Bi M, Finger EB, Szot G, Ye J, Masteller EL, McDevitt H, Bonyhadi M, and Bluestone JA (2004) In vitro-expanded antigen-specific regulatory T cells suppress autoimmune diabetes. J Exp Med 199(11):1455-65

50. Akiyama T, Maeda S, Yamane S, Ogino K, Kasai M, Kajiura F, Matsumoto M, and Inoue J (2005) Dependence of self-tolerance on TRAF6-directed development of thymic stroma. Science 308(5719):248-51

51. Kajiura F, Sun S, Nomura T, Izumi K, Ueno T, Bando Y, Kuroda N, Han H, Li Y, Matsushima A, Takahama Y, Sakaguchi S, Mitani T, and Matsumoto M (2004) NF-kappa B-inducing kinase establishes self-tolerance in a thymic stroma-dependent manner. J Immunol 172(4):2067-75

52. Mathis D and Benoist C (2007) A decade of AIRE. Nat Rev Immunol 7(8):645-50

53. Hori S, Haury M, Coutinho A, and Demengeot J (2002) Specificity requirements for selection and effector functions of $\mathrm{CD} 25+4+$ regulatory $\mathrm{T}$ cells in anti-myelin basic protein T cell receptor transgenic mice. Proc Natl Acad Sci U S A 99(12):8213-8

54. Hsieh CS, Zheng Y, Liang Y, Fontenot JD, and Rudensky AY (2006) An intersection between the self-reactive regulatory and nonregulatory $\mathrm{T}$ cell receptor repertoires. Nat Immunol 7(4):401-10

55. Pacholczyk R, Kern J, Singh N, Iwashima M, Kraj P, and Ignatowicz L (2007) Nonself-antigens are the cognate specificities of Foxp3+ regulatory $\mathrm{T}$ cells. Immunity 27(3):493-504

56. Kuczma M, Pawlikowska I, Kopij M, Podolsky R, Rempala GA, and Kraj P (2009) TCR repertoire and Foxp3 expression define functionally distinct subsets of CD4+ 
regulatory T cells. J Immunol 183(5):3118-29

57. Hsieh CS, Liang Y, Tyznik AJ, Self SG, Liggitt D, and Rudensky AY (2004) Recognition of the peripheral self by naturally arising CD25+CD4+ T cell receptors. Immunity 21(2):267-77

58. Andersson J, Stefanova I, Stephens GL, and Shevach EM (2007) CD4+CD25+ regulatory $\mathrm{T}$ cells are activated in vivo by recognition of self. Int Immunol 19(4):557-66

59. Gavin MA, Rasmussen JP, Fontenot JD, Vasta V, Manganiello VC, Beavo JA, and Rudensky AY (2007) Foxp3-dependent programme of regulatory T-cell differentiation. Nature 445(7129):771-5

60. Lahl K, Mayer CT, Bopp T, Huehn J, Loddenkemper C, Eberl G, Wirnsberger G, Dornmair K, Geffers R, Schmitt E, Buer J, and Sparwasser T (2009) Nonfunctional regulatory $\mathrm{T}$ cells and defective control of Th2 cytokine production in natural scurfy mutant mice. J Immunol 183(9):5662-72

61. Sugimoto N, Oida T, Hirota K, Nakamura K, Nomura T, Uchiyama T, and Sakaguchi S (2006) Foxp3-dependent and -independent molecules specific for CD25+CD4+ natural regulatory $\mathrm{T}$ cells revealed by DNA microarray analysis. Int Immunol 18(8):1197-209

62. Hill JA, Feuerer M, Tash K, Haxhinasto S, Perez J, Melamed R, Mathis D, and Benoist C (2007) Foxp3 transcription-factor-dependent and -independent regulation of the regulatory $\mathrm{T}$ cell transcriptional signature. Immunity 27(5):786-800

63. Tone Y, Furuuchi K, Kojima Y, Tykocinski ML, Greene MI, and Tone M (2008) Smad3 and NFAT cooperate to induce Foxp3 expression through its enhancer. Nat Immunol 9(2):194-202

64. Kim HP and Leonard WJ (2007) CREB/ATF-dependent T cell receptor-induced FoxP3 gene expression: a role for DNA methylation. J Exp Med 204(7):1543-51

65. Mucida D, Park Y, Kim G, Turovskaya O, Scott I, Kronenberg M, and Cheroutre H (2007) Reciprocal TH17 and regulatory T cell differentiation mediated by retinoic acid. Science 317(5835):256-60

66. Sun CM, Hall JA, Blank RB, Bouladoux N, Oukka M, Mora JR, and Belkaid Y (2007) Small intestine lamina propria dendritic cells promote de novo generation of Foxp3 T reg cells via retinoic acid. J Exp Med 204(8):1775-85 
67. Benson MJ, Pino-Lagos K, Rosemblatt M, and Noelle RJ (2007) All-trans retinoic acid mediates enhanced $\mathrm{T}$ reg cell growth, differentiation, and gut homing in the face of high levels of co-stimulation. J Exp Med 204(8):1765-74

68. Siddiqui KR and Powrie F (2008) CD103+ GALT DCs promote Foxp3+ regulatory T cells. Mucosal Immunol 1 Suppl 1:S34-8

69. Zheng Y, Josefowicz SZ, Kas A, Chu TT, Gavin MA, and Rudensky AY (2007) Genome-wide analysis of Foxp3 target genes in developing and mature regulatory $\mathrm{T}$ cells. Nature 445(7130):936-40

70. Marson A, Kretschmer K, Frampton GM, Jacobsen ES, Polansky JK, MacIsaac KD, Levine SS, Fraenkel E, von Boehmer H, and Young RA (2007) Foxp3 occupancy and regulation of key target genes during T-cell stimulation. Nature 445(7130):931-5

71. Koch MA, Tucker-Heard G, Perdue NR, Killebrew JR, Urdahl KB, and Campbell DJ (2009) The transcription factor T-bet controls regulatory $\mathrm{T}$ cell homeostasis and function during type 1 inflammation. Nat Immunol 10(6):595-602

72. Zheng Y, Chaudhry A, Kas A, deRoos P, Kim JM, Chu TT, Corcoran L, Treuting P, Klein U, and Rudensky AY (2009) Regulatory T-cell suppressor program co-opts transcription factor IRF4 to control T(H)2 responses. Nature 458(7236):351-6

73. Chaudhry A, Rudra D, Treuting P, Samstein RM, Liang Y, Kas A, and Rudensky AY (2009) CD4+ Regulatory T Cells Control TH17 Responses in a Stat3-Dependent Manner. Science

74. Li B and Greene MI (2007) FOXP3 actively represses transcription by recruiting the HAT/HDAC complex. Cell Cycle 6(12):1432-6

75. Bettelli E, Dastrange M, and Oukka M (2005) Foxp3 interacts with nuclear factor of activated T cells and NF-kappa B to repress cytokine gene expression and effector functions of T helper cells. Proc Natl Acad Sci U S A 102(14):5138-43

76. Ono M, Yaguchi H, Ohkura N, Kitabayashi I, Nagamura Y, Nomura T, Miyachi Y, Tsukada T, and Sakaguchi S (2007) Foxp3 controls regulatory T-cell function by interacting with AML1/Runx1. Nature 446(7136):685-9

77. Ichiyama K, Yoshida H, Wakabayashi Y, Chinen T, Saeki K, Nakaya M, Takaesu G, Hori S, Yoshimura A, and Kobayashi T (2008) Foxp3 inhibits RORgammat-mediated IL-17A mRNA transcription through direct interaction with RORgammat. J Biol Chem 283(25):17003-8 
78. Pan F, Yu H, Dang EV, Barbi J, Pan X, Grosso JF, Jinasena D, Sharma SM, McCadden EM, Getnet D, Drake CG, Liu JO, Ostrowski MC, and Pardoll DM (2009) Eos mediates Foxp3-dependent gene silencing in CD4+ regulatory $\mathrm{T}$ cells. Science 325(5944):1142-6

79. Chen C, Rowell EA, Thomas RM, Hancock WW, and Wells AD (2006) Transcriptional regulation by Foxp3 is associated with direct promoter occupancy and modulation of histone acetylation. J Biol Chem 281(48):36828-34

80. Aramburu J, Heitman J, and Crabtree GR (2004) Calcineurin: a central controller of signalling in eukaryotes. EMBO Rep 5(4):343-8

81. Aramburu J, Garcia-Cozar F, Raghavan A, Okamura H, Rao A, and Hogan PG (1998) Selective inhibition of NFAT activation by a peptide spanning the calcineurin targeting site of NFAT. Mol Cell 1(5):627-37

82. Okamura H, Aramburu J, Garcia-Rodriguez C, Viola JP, Raghavan A, Tahiliani M, Zhang X, Qin J, Hogan PG, and Rao A (2000) Concerted dephosphorylation of the transcription factor NFAT1 induces a conformational switch that regulates transcriptional activity. Mol Cell 6(3):539-50

83. Rao A, Luo C, and Hogan PG (1997) Transcription factors of the NFAT family: regulation and function. Annu Rev Immunol 15:707-47

84. Wu Y, Borde M, Heissmeyer V, Feuerer M, Lapan AD, Stroud JC, Bates DL, Guo L, Han A, Ziegler SF, Mathis D, Benoist C, Chen L, and Rao A (2006) FOXP3 controls regulatory $\mathrm{T}$ cell function through cooperation with NFAT. Cell 126(2):375-87

85. Ranger AM, Oukka M, Rengarajan J, and Glimcher LH (1998) Inhibitory function of two NFAT family members in lymphoid homeostasis and Th2 development. Immunity 9(5):627-35

86. Ito Y (2008) RUNX genes in development and cancer: regulation of viral gene expression and the discovery of RUNX family genes. Adv Cancer Res 99:33-76

87. Taniuchi I, Osato M, Egawa T, Sunshine MJ, Bae SC, Komori T, Ito Y, and Littman DR (2002) Differential requirements for Runx proteins in CD4 repression and epigenetic silencing during T lymphocyte development. Cell 111(5):621-33

88. Li QL, Ito K, Sakakura C, Fukamachi H, Inoue K, Chi XZ, Lee KY, Nomura S, Lee CW, Han SB, Kim HM, Kim WJ, Yamamoto H, Yamashita N, Yano T, Ikeda T, Itohara S, Inazawa J, Abe T, Hagiwara A, Yamagishi H, Ooe A, Kaneda A, Sugimura T, 
Ushijima T, Bae SC, and Ito Y (2002) Causal relationship between the loss of RUNX3 expression and gastric cancer. Cell 109(1):113-24

89. Kitoh A, Ono M, Naoe Y, Ohkura N, Yamaguchi T, Yaguchi H, Kitabayashi I, Tsukada T, Nomura T, Miyachi Y, Taniuchi I, and Sakaguchi S (2009) Indispensable role of the Runx1-Cbfbeta transcription complex for in vivo-suppressive function of FoxP3+ regulatory T cells. Immunity 31(4):609-20

90. Sasaki K, Yagi H, Bronson RT, Tominaga K, Matsunashi T, Deguchi K, Tani Y, Kishimoto T, and Komori T (1996) Absence of fetal liver hematopoiesis in mice deficient in transcriptional coactivator core binding factor beta. Proc Natl Acad Sci U S A 93(22):12359-63

91. Wang Q, Stacy T, Miller JD, Lewis AF, Gu TL, Huang X, Bushweller JH, Bories JC, Alt FW, Ryan G, Liu PP, Wynshaw-Boris A, Binder M, Marin-Padilla M, Sharpe AH, and Speck NA (1996) The CBFbeta subunit is essential for CBFalpha2 (AML1) function in vivo. Cell 87(4):697-708

92. Rudra D, Egawa T, Chong MM, Treuting P, Littman DR, and Rudensky AY (2009) Runx-CBFbeta complexes control expression of the transcription factor Foxp3 in regulatory T cells. Nat Immunol 10(11):1170-7

93. Bruno L, Mazzarella L, Hoogenkamp M, Hertweck A, Cobb BS, Sauer S, Hadjur S, Leleu M, Naoe Y, Telfer JC, Bonifer C, Taniuchi I, Fisher AG, and Merkenschlager M (2009) Runx proteins regulate Foxp3 expression. J Exp Med 206(11):2329-37

94. Sakaguchi S (2004) Naturally arising CD4+ regulatory $t$ cells for immunologic self-tolerance and negative control of immune responses. Annu Rev Immunol 22:531-62

95. Brenner O, Levanon D, Negreanu V, Golubkov O, Fainaru O, Woolf E, and Groner Y (2004) Loss of Runx3 function in leukocytes is associated with spontaneously developed colitis and gastric mucosal hyperplasia. Proc Natl Acad Sci U S A 101(45):16016-21

96. Prokunina L, Castillejo-Lopez C, Oberg F, Gunnarsson I, Berg L, Magnusson V, Brookes AJ, Tentler D, Kristjansdottir H, Grondal G, Bolstad AI, Svenungsson E, Lundberg I, Sturfelt G, Jonssen A, Truedsson L, Lima G, Alcocer-Varela J, Jonsson R, Gyllensten UB, Harley JB, Alarcon-Segovia D, Steinsson K, and Alarcon-Riquelme ME (2002) A regulatory polymorphism in PDCD1 is associated with susceptibility to 
systemic lupus erythematosus in humans. Nat Genet 32(4):666-9

97. Helms C, Cao L, Krueger JG, Wijsman EM, Chamian F, Gordon D, Heffernan M, Daw JA, Robarge J, Ott J, Kwok PY, Menter A, and Bowcock AM (2003) A putative RUNX1 binding site variant between SLC9A3R1 and NAT9 is associated with susceptibility to psoriasis. Nat Genet 35(4):349-56

98. Tokuhiro S, Yamada R, Chang X, Suzuki A, Kochi Y, Sawada T, Suzuki M, Nagasaki M, Ohtsuki M, Ono M, Furukawa H, Nagashima M, Yoshino S, Mabuchi A, Sekine A, Saito S, Takahashi A, Tsunoda T, Nakamura Y, and Yamamoto K (2003) An intronic SNP in a RUNX1 binding site of SLC22A4, encoding an organic cation transporter, is associated with rheumatoid arthritis. Nat Genet 35(4):341-8

99. Kikly K, Liu L, Na S, and Sedgwick JD (2006) The IL-23/Th(17) axis: therapeutic targets for autoimmune inflammation. Curr Opin Immunol 18(6):670-5

100. Aujla SJ, Dubin PJ, and Kolls JK (2007) Th17 cells and mucosal host defense. Semin Immunol 19(6):377-82

101. Kottke T, Sanchez-Perez L, Diaz RM, Thompson J, Chong H, Harrington K, Calderwood SK, Pulido J, Georgopoulos N, Selby P, Melcher A, and Vile R (2007) Induction of hsp70-mediated Th17 autoimmunity can be exploited as immunotherapy for metastatic prostate cancer. Cancer Res 67(24):11970-9

102. Mangan PR, Harrington LE, O'Quinn DB, Helms WS, Bullard DC, Elson CO, Hatton RD, Wahl SM, Schoeb TR, and Weaver CT (2006) Transforming growth factor-beta induces development of the T(H)17 lineage. Nature 441(7090):231-4

103. Chen W, Jin W, Hardegen N, Lei KJ, Li L, Marinos N, McGrady G, and Wahl SM (2003) Conversion of peripheral CD4+CD25- naive T cells to CD4+CD25+ regulatory $\mathrm{T}$ cells by TGF-beta induction of transcription factor Foxp3. $\mathrm{J}$ Exp Med 198(12):1875-86

104. Shi Y, Sawada J, Sui G, Affar el B, Whetstine JR, Lan F, Ogawa H, Luke MP, and Nakatani Y (2003) Coordinated histone modifications mediated by a CtBP co-repressor complex. Nature 422(6933):735-8

105. Fisson S, Darrasse-Jeze G, Litvinova E, Septier F, Klatzmann D, Liblau R, and Salomon BL (2003) Continuous activation of autoreactive CD4+ CD25+ regulatory T cells in the steady state. J Exp Med 198(5):737-46

106. Floess S, Freyer J, Siewert C, Baron U, Olek S, Polansky J, Schlawe K, Chang HD, 
Bopp T, Schmitt E, Klein-Hessling S, Serfling E, Hamann A, and Huehn J (2007) Epigenetic control of the foxp3 locus in regulatory T cells. PLoS Biol 5(2):e38

107. Sanchez-Abarca LI, Gutierrez-Cosio S, Santamaria C, Caballero-Velazquez T, Blanco B, Herrero-Sanchez C, Garcia JL, Carrancio S, Hernandez-Campo P, Gonzalez FJ, Flores T, Ciudad L, Ballestar E, Del Canizo C, San Miguel JF, and Perez-Simon JA (2009) Immunomodulatory effect of 5-azacytidine (5-azaC): potential role in the transplantation setting. Blood

108. Josefowicz SZ, Wilson CB, and Rudensky AY (2009) Cutting edge: TCR stimulation is sufficient for induction of Foxp3 expression in the absence of DNA methyltransferase 1. J Immunol 182(11):6648-52 


\section{Figure legends}

Fig. 1. A possible mechanism of Foxp3-mediated Treg function. Upon TCR engagement with self-peptide/MHC ligands, transcriptional factors that bind to the promoter or enhancer region of the Foxp3 gene control Foxp3 expression. Foxp3-dependent transcriptional regulation also requires direct interaction with other transcription factors including NFAT, Runx1, ROR $\gamma \mathrm{t}$ and Eos. These interactions are critical for Treg function and development. 


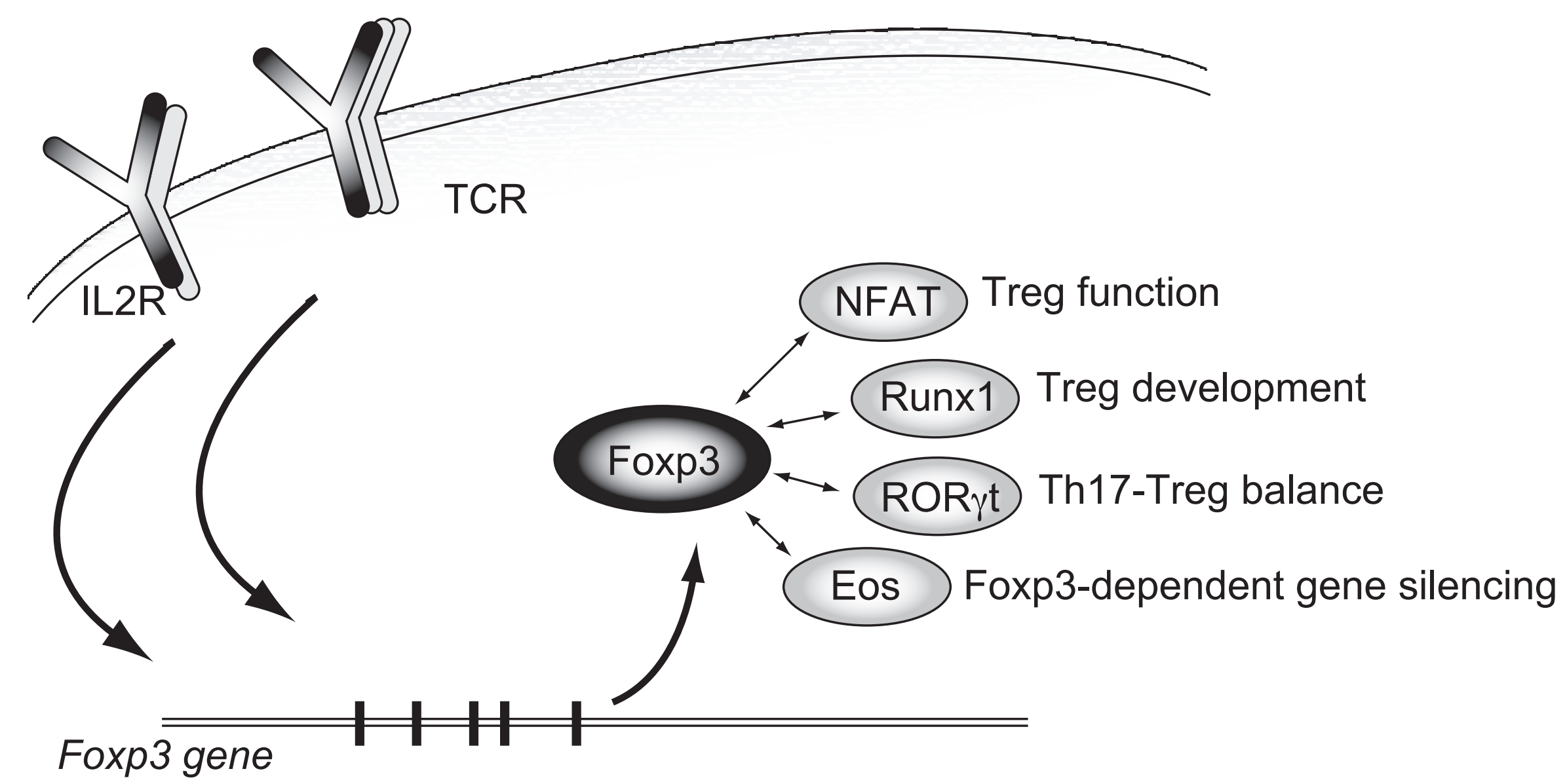

